\title{
An Analysis of Deixis to Song Lyrics "My Heart Will Go on" by Celine Dion
}

\author{
Nguyen Van Thao ${ }^{1}$, Herman $^{2}$ \\ ${ }^{1}$ Faculty of Philology, Hanoi Pedagogical University 2, Vinh Phuc, Vietnam \\ ${ }^{2}$ Department of English Education, Universitas HKBP Nommensen, Medan, Indonesia
}

Email address:

nguyenvanthao@hpu2.edu.vn (N. V. Thao),herman@uhn.ac.id (Herman)

\section{To cite this article:}

Nguyen Van Thao, Herman. An Analysis of Deixis to Song Lyrics "My Heart Will Go on" by Celine Dion. Communication and Linguistics Studies. Vol. 6, No. 2, 2020, pp. 23-26. doi: 10.11648/j.cls.20200602.12

Received: March 26, 2020; Accepted: April 10, 2020; Published: April 29, 2020

\begin{abstract}
Deixis refers to words and phrases, such as "me" or "here" that cannot fully understood without additional contextual information or deixis that point to the time, place, or situation in which a speaker is speaking. Deixis is used in most conversation or writing of literary works such as writing of song lyrics. In this time, the researchers are interested to analyze how many deixis such as personal deixis, place deixis and time deixis is used in lyrics song by Celine Dion. Lyrics of song same with poetry because song is a poem sung. In this research, the researchers used Celine Dion's lyrics song that rewritten and analyzed every single word. Problem raised in this research was What kinds of deixis found in the lyrics song "My Heart Will Go On' by Celine Dion? To answer the questions, some theories used in this research namely Bouk (2016), Brown and Yule (1983), Peccei (1999) and Yule (1996). Qualitative research was conducted in this research with the source data taken from the lyrics of the song. The lyrics were analyzed using the theories and to be classified into the types of deixis based on the theories provided. After analyzing the data, the researchers found that there were three parts of deixis depicted in the lyrics song, namely: Personal deixis, Spatial deixis and Temporal deixis.
\end{abstract}

Keywords: Deixis, Lyrics, Song, Pragmatics

\section{Introduction}

Human cannot be separated with social relation in their lives. To have a social relation, communication is needed. Language is as the tool of communication that has the essential part in making communication [8]. All communication can be done in verbal and visual as long as the intention of the communication can get to the hearer or listener. To make it easier, media is needed to make it happens. There are many literary works as the media of expressing idea, opinion and thought such as poetry, novel, film, song and others. The main function of literary work is to entertain reader or hearer. One of them of literary work is song. Song is focused in this research.

Song is a one of the ways to communicate the enables human to cooperate [14]. Song is considered to be a system of communication with other people using sounds and song to express a feeling, sense, idea, emotion or thought. Nowadays people are easy and like to show their feeling by writing the song. Song is another way to communicate people's feeling to someone else that is through lyrics. Lyrics is not only arrangement of words into sentences but also representation of the composers emotion to describe the feelings such as falling in love, sad, happy, jealous, broken heart, missing someone hate someone and others. This is in line with Sitorus and Herman's statement. They stated that lyric is the words of song, especially a pop song, or a short poem which express the personal thoughts and feelings of the person who wrote it [14]. Every lyrics consist of words or sentences which have different grammatical functions and song lyrics could be said as part of discourse.

Brown and Yule state that the analysis of discourse is necessary of language in use [4]. Discourse is more than a message from a sender to a receiver and a reader or listener is much more than just receiver who decodes incoming signal. In this research, the researchers use pragmatic approach. Pragmatics is study of speaker meaning [15]. This means that pragmatics is concerned with the study of meaning as communicated by a speaker and interpreted by a listener. Pragmatics focuses a study like deictic, reference, entailment, 
and speech act and so on. And in this research, the researchers are interested to analyze the kinds of deictic analysis of song lyrics in Celine Dion song and also the meaning of deixis song lyrics in song of Celine Dion. But in this research, the researchers focus to analyze the person deixis, place deixis and time deixis from song lyrics popular from Celine Dion namely My heart will go on. Based on phenomenon above, the researcher conduct a research entitled An Analysis of Deixis to Song Lyrics of "My Heart Will Go On" by Celine Dion.

\section{Theoretical Review}

\subsection{Pragmatic}

Pragmatics as the study of relationships between linguistic forms and the users of those forms and pragmatics is the only one allowing human into the analysis because through pragmatics one can talk about people's intended meanings, their assumptions, their purposes, and the kinds of actions such as requests and apologizes when they speak [15]. Hence, Pragmatics concentrates on those aspects of meaning that cannot be predicted by linguistic knowledge alone and takes into account knowledge about the physical and social world [13]. Furthermore, Pragmatics studies the factors that govern our choice of language in social interaction and the effects of our choice on others [7]. From the three definitions above, the researchers conclude that pragmatics is the study about language use in understanding someone's intention when doing communication.

\subsection{Definitions of Deixis}

In linguistics, deixis refers to words and phrases, such as "me" or "here", that cannot be fully understood without additional contextual information. Deixis is actually a technical term (from Greek) which means 'pointing' through language [15]. Then, Deixis means different things to different people [6]. Hence, deixis means pointing via language, and it is concerned with the ways in which language encodes the features of the context of utterance or speech event [3]. These definitions mentioned above express that in doing the communication, deixis plays an important part whether in the context of utterance of speech event.

\subsection{Types of Deixis}

There is a deictic centre that consists of I, Here and Now [10].

\section{A.Person Deixis}

The choice of one form will certainly communicative something (not directly said) about the speaker's view of his or her relationship with the addressee [15]. Person deixis concerns with the encoding of the role of participants in the speech event, in which the utterance in question is delivered: the category first person is the grammaticalization of the speaker's reference to himself, second person the encoding of reference to one or more addresses and third person the encoding of reference to persons and entities which are neither speakers nor addresses of the utterance in question [10].

\section{Example:}

I am going to the movies

Would you like to have dinner?

They tried to hurt me, but she came to the rescue

In language (like English) with gendered pronouns, the third person masculine pronoun has traditionally been used as a default when using "it" is inappropriate but the gender of its antecedent is unknown or inapplicable.

\section{B. Place Deixis}

The kind of deixis, known as spatial or space deixsis, is also associated with the adverbs here and there and some uses of prepositions such as in or on (e.g. in the room, on the roof) [11]. Hence, Place deixis (spatial deixis) is the specification of locations relative to anchorage points in the speech event [10].

Example:

I enjoy living in this city

Here is where we will place the statue

She was sitting over there

C. Time Deixis

Time deixis or known as temporal deixis refers to indicate a time such as now, then, next week, last month and so on for interpreting most of the deictic expressions that the speakers have in their mind. Temporal in dexicals are expressed in time adverbials like "now, soon, lately, recently, ago, today, tomorrow, yesterday [15].

For example, in were to write.

It is raining now, but $\mathrm{i}$ hope when you read this it will be sunny.

\section{Research Methodology}

Qualitative research seeks to understand a phenomenon by focusing on the total picture rather than breaking it down into variables [12]. Source of data on this study is song lyrics from Celine Dion namely My heart will go on. Data collected by listening the song and reading the lyrics, then the data was collected include (1) the collection of data usage deixis persona or person deixis, time deixis and place deixis in song lyrics from song Celine Dion (2) sorting, classification, and analysis of data on the use kinds of deixis.

There are some procedures in analyzing the data, they are:

1. Collecting data usage of deixis.

2. Identifying any classify the data usage of deixis person, deixis place and deixis time.

3. Analyzing data of usage the deixis, and,

4. Making the conclusion usage of deixis data.

\section{Data Analysis and Finding}

Based on the data analysis, a song lyrics popular of Celine Dion namely My heart will go on a number of deixis namely person deixis, place deixis, time deixis, discourse deixis, and social deixis. But in this research focus for three of them namely person deixis place deixis and time deixis. Each data 
analysis the kinds of deixis from song lyrics of Celine Dion is presented below:

\section{Celine Dion ( My heart will go on)}

From the title above, My heart will go on can be inferred that the song tell about love which the in this song the composer sure that they love will stay forever eventhough there a spaces between them. In this song the song writer uses three types of deixis there are person deixis, place/spatial deixis and time/temporal deixis.

From the tabulated above, the writer founds that the song writer uses singular person deixis "I" and "my" then the plural first person deixis "we" and second person deixis "you"

"every night in my dream, I see you, I feel you"

"that is how I know you go on

"far across the distance and spaces between us "

From lyrics above, it can be seen that the writer uses first person singular deixis "I" to refer itself that in her every night, who she can see and feel you.(you) is the second participant. The use of first person singular makes who to talk in this song

The deictic "my" in song above is form of possessive adjective referring to something belong to her. The word "my" is one of deictic expression which is pointed to something belong to the song writer. "my" applied by the song writer for indicate that the song uses the deictic expression possessive adjective

The deictic "us" is the expression that usually indicates that the speaker is speaking as the representation of other speaker. Its mean more than one speaker or participants involved in this song and show the song uses the deictic expression to addressed the listener and the speaker and the writer uses deictic "you" as the second participant in that song. Also you are as an object because the hearer obtained an action by the speaker "you" is the listener as the addressee who loved by the speaker.

"every night in dream, see, feel"

"that is how know go on"

"far across the distance and spaces between "

From the text without the expression deictic it will be confusion for the listener of song, which the speaker is the song. The song listener will be not know what the song tells about, whether talk about the song writer herself or other person. So its mean the use of deixis affecting of the whole lyrics of song and it can be seen if the writer omitted the deictic expression namely person deixis.

Second type of deixis is spatial or place deixis. From the tabulated above, it can be seen the writer use place deixis "wherever as the adverb expression deictic. In this case the speaker is love and the speaker still love near or far the hearer are. and also use "here" as the expression deictic to show that the speaker also still love the second participant in that song "you"

"near, far, wherever you are"

"i believe that the heart does go on"

"once more you open the door"

"And you're here in my heart and my heart will go on and on"

The use of place deixis explain in song to explain the location the speaker is and it will add the listener knowledge about the place. If the writer of song not use place deixis it will be make confusion to the song listener where the location.

Last the kinds of deixis namely temporal or time deixis. In that use in the song lyrics the writer of song refer to condition how the speaker love between the first person participant and the second person participant. The speaker always loves and never let go till they're gone. Deictic expression "one time" and "lifetime" show the time. In the lyrics it is refers to the time where the song writer and the hearer know that they love never let go

"love can touch us one time and last for a lifetime"

"and never let go till we're gone"

For knowing how the use of the deixis affecting the meaning it can be seen if the writer ommited the deictic expression of time deixis

"love can touch us and last for a"

"and never let go till we're gone"

The use of temporal deixis used the point a time about the speaker and the hearer love. without using the expression deictic the listener song will be not understand the meaning of song lyrics, the listener will know when the time is. The use of deixis in lyrics, affect the meaning of whole the lyrics of song. With the use of deictic expression make easier the listener to understand the lyrics of song.

For the analysis of Person deixis can be seen in the following table below:

Table 1. List of Deixis in the Song lyrics of "My Heart Will Go On".

\begin{tabular}{|c|c|c|c|}
\hline No & Lyrics & Types of Deixis & Meaning Deixis in Semantics \\
\hline 1 & Every night in my dreams & $\begin{array}{l}\text { Every night (time deixis) } \\
\text { My (person deixis) }\end{array}$ & "My" as the first person who said that every night in her dream \\
\hline 2 & I see you, I feel you & I, you (person deixis) & $\begin{array}{l}\text { "I" as the first participants said if she can see and feel "you"as the second } \\
\text { participants }\end{array}$ \\
\hline 3 & That is how i know you go on & I, you (person deixis) & "I" as the first participants said that know "you" as second participant will go on \\
\hline 4 & $\begin{array}{l}\text { Far across the distance and } \\
\text { spaces between us }\end{array}$ & We (person deixis) & $\begin{array}{l}\text { "we" namely is first participant I and the second participant is you if the far } \\
\text { across the distance and spaces between them }\end{array}$ \\
\hline 6 & Near, far, wherever you are & $\begin{array}{l}\text { Wherever ( place deixis) You } \\
\text { (person deixis) }\end{array}$ & Wherever "you"as the second participant are, near or far \\
\hline 7 & $\begin{array}{l}\text { I believe that the heart does go } \\
\text { on }\end{array}$ & I (person deixis) & "I" as the first participant said that if she belives the heart does does go on \\
\hline
\end{tabular}




\begin{tabular}{|c|c|c|c|}
\hline No & Lyrics & Types of Deixis & Meaning Deixis in Semantics \\
\hline 8 & Once more you open the door & $\begin{array}{l}\text { Once more (time deixis) } \\
\text { You (person deixis) }\end{array}$ & "you" as the second participant open the door \\
\hline 9 & $\begin{array}{l}\text { And you're here in my heart } \\
\text { and my heart will go on and on }\end{array}$ & $\begin{array}{l}\text { You, my (person deixis) } \\
\text { Here (place deixis) }\end{array}$ & $\begin{array}{l}\text { "you" as the second participant always stay in heart of the first participant "my" } \\
\text { and "my" as the first participant said that my heart will go on and on }\end{array}$ \\
\hline 10 & $\begin{array}{l}\text { Love can touch us one time and } \\
\text { last for a lifetime }\end{array}$ & $\begin{array}{l}\text { Us (person deixis) } \\
\text { One time, lifetime (time deixis) }\end{array}$ & The love can touch "us" between I and you one time and last for a lifetime \\
\hline 11 & And never let go till we're gone & We (person deixis) & "we" its mean between I and you never let go till they're gone \\
\hline 12 & Love was when I loved you & I, you (person deixis) & $\begin{array}{l}\text { "I" as the participant said if love was when she (I) loved "you" as the second } \\
\text { participant }\end{array}$ \\
\hline 13 & One true time I hold to & $\begin{array}{l}\text { One true time (time deixis) } \\
\text { I (person deixis) }\end{array}$ & "I" said that one true time I hold to "I" as the first participant \\
\hline 14 & In my life we'll always go on & My, we (person deixis) & $\begin{array}{l}\text { "My"said that in her life "we".(we is between first participant and the second } \\
\text { participant) always go on }\end{array}$ \\
\hline 15 & $\begin{array}{l}\text { You're here, there 's nothing I } \\
\text { fear }\end{array}$ & $\begin{array}{l}\text { You, I (person deixis) } \\
\text { Here (place deixis) }\end{array}$ & $\begin{array}{l}\text { "you" as the second participant here, so "I" as the first participant said that } \\
\text { there's nothing fear }\end{array}$ \\
\hline 16 & $\begin{array}{l}\text { And i know that my heart my } \\
\text { heart will go on }\end{array}$ & I, my (person deixis ) & "I" as the first participant know that her heart (My) will go on \\
\hline 17 & We'll stay forever this way & We (person deixis) & "we" its mean between first participant and the second participant \\
\hline 18 & You are safe in my heart & You, my (person deixis) & "you" as the second participant are safe in my heart.(my) as the first participant \\
\hline 19 & And my heart will go on and on & My ( person deixis) & "My" as the first participant said that her heart will go on and on \\
\hline
\end{tabular}

\section{Conclusion}

After analyzing the data, there are three types of deixis depicted in song lyrics from Celine Dion "My heart will go on "they are person dexis, spatial or place deixis and time or temporal deixis. Person dexis is function to find the participant role in participant. Therefore by using the person deixis it will make the song listener understand the message easier. Based the data analysis there are three of types of deixis in song lyrics of Celine Dion "My heart will go on" namely the first is person deixis, the second deixis is place deixis and the third is time deixis. From the three types of deixis person deixis it most use in song lyrics by Celine Dion namely the first person singular "I" because this song lyrics tell about the composer or the song writer. Place deixis indicating the place between the speaker and the hearer are including the location "here" etc. Temporal deixis used to point to a time of event, including the adverb time namely one "time", "lifetime". etc. The researchers conclude that the deixis is useful to describe the function of person deixis, time deixis and place deixis to analysis the song lyrics, the writer concludes that the deixis meaning can be analyzed semantically to know how the substantively meaning and how the affects of the use deixis for the whole lyrics song.

\section{References}

[1] Austin, J. L. (1962). How to do Things with words, Michigan: President and Fellows.

[2] Austin, J. L. (1975). How to Do Things with Words (2nd ed). Oxford: Oxford University Press.

[3] Bouk, E. (2016). pragmatic analysis of deixis in the speeches of Xanana Gusmao-The former prime minister of Timor Leste. Jurnal Tutur. Vol. 2, No. 2 Agustus 2016. ISSN: 2442-3475.

[4] Brown, G. dan Yule, G. (1983). Discourse analysis. Oxford: Oxford University Press.
[5] Cohen, L. (2007). Research methods in education. London: Routledge.

[6] Cruse, Alan D. (2000). Meaning in Language: An Introduction to Semantics and Pragmatics. New York: Oxford University Press.

[7] Herman. (2015). Illocutionary acts analysis of Chinese in Pematangsiantar. International Journal of Humanities and Social Science Invention. ANED. 29.7722/0401202041048.

[8] Herman and Silalahi, D. E. (2020). Critical discourse analysis on "We are the World 25 for Haiti" song lyrics. Journal of English Education and Teaching (JEET), Volume 4 number 1, March 2020, Page 36-48.

[9] Hutajulu, F. S. L. and Herman. (2019). Analysis of illocutionary act in the movie "You are My Home" English Subtitle. Journal of English Educational Study, Volume 2, Issue 1 May 2019, Page 29-36, 2019. DOI: 10.31932/jees.v2i1.371.

[10] Levinson, S. C. (1983). Pragmatics. London: Cambridge University Press.

[11] Mayer, C. F. 2009. Introducing English linguistics. Oxford, New York: Oxford University Press.

[12] Pardede, H., Herman and Pratiwi, W. (2019). An analysis of politeness principle maxims found in Big Hero 6 movie. European Exploratory Scientific Journal, Vol 3 №4, 2019.

[13] Peccei, J. S. (1999). Pragmatics. London: Taylor and Francis Limited.

[14] Sitorus, E. and Herman. (2019). A deixis analysis of song lyrics in Calum Scott "You Are the Reason". International Journal of Science and Qualitative Analysis, 5 (1), 24-28. DOI: $10.11648 / j$.ijsqa.20190501.14.

[15] Yule, G. (1996). Pragmatics. Oxford: Oxford University Press.

[16] https://www.azlyrics.com/lyrics/celinedion/myheartwillgoon.h tml. 